\title{
Effect of high crude fibre feed towards digestive tract characteristics of crossbreed native chicken
}

\author{
Yusti Pujiawati ${ }^{*}$ Ida Ayu Putu Parwati, and I Nyoman Suyasa \\ Bali Assessment Institute for Agricultural Technology (AIAT), Jalan By Pass Ngurah Rai \\ Pesanggaran Denpasar Selatan 80222 Indonesia
}

\begin{abstract}
This research was aimed to evaluate the use of high crude fibre feed on the characteristic of the native chicken digestive tracts. The research was conducted in Tembuku District, Bangli Regency in AprilAugust 2020. There were four treatments starter diets included P0 (control), P1 $(70 \%$ control feed $+30 \%$ rice bran), P2 $(70 \%$ control feed $+30 \%+$ Bio B 2cc/l drinking water), P3 $(60 \%$ control feed $+10 \%$ Indigofera meal $+30 \%$ rice bran), while four treatment grower diet included P0 $(25 \%$ control feed $+35 \%$ rice bran $+40 \%$ corn $)$, P1 (15\% control feed $+35 \%$ rice bran $+10 \%$ Indigofera meal $+40 \%$ corn $)$, P2 (15\% control feed $+35 \%$ rice bran $+10 \%$ Indigofera meal $+40 \%$ corn $+2 \mathrm{cc} / 1 \mathrm{Bio}-\mathrm{B})$, and $\mathrm{P} 3$ ( $22 \%$ control feed $+31.5 \%$ rice bran $+10 \%$ Indigofera meal $+36.5 \%$ corn). The variables observed included final body weight, digestive tract weight, and digestive tract length. A factorial randomized block design was used in this study with univariate analysis and further Duncan test. This study showed that high crude fibre feed affected the digestive tract, such as the weight of the duodenum, jejunum, ileum, cecum, liver, pancreas, proventriculus. This also occurred in the parameters of the length of the duodenum, jejunum, ileum, cecum, and colon.
\end{abstract}

\section{Introduction}

The native chicken has a few primacies such as consumer preferences for eggs and meat products are quite high, price is more stable, and high adaptability to the tropical climate [1]. Kampung Unggul Balitbangtan (KUB) chicken is a crossbreed native chicken that has undergone selection, becoming a dual-purpose chicken as an egg and meat producer. The KUB chicken has a few primacies, such as low feed conversion ratio, good immunity, lowrate mortality, and high egg productivity [2]. Furthermore, Indonesian Agency for Agricultural Research and Development (IAARD) also carried out a genetic selection of Sentul Native Chicken becoming Sensi-1 Agrinak Chicken. Sensi-1 Agrinak chicken is a broiler type with a few primacies, such as a live weight greater than native chicken, the live

\footnotetext{
* Corresponding author: yustipwiradinata@gmail.com
} 
weight of male Sensi-1 Agrinak chicken of 10 weeks age reach $1066 \pm 62.5$ gram/head, while female Sensi-1 Agrinak chicken reaches 745 $\pm 114 \mathrm{gram} / \mathrm{head}$ [3].

Crosses breed of KUB chickens and Sensi-1 Agrinak chickens are expected to produce dual-purpose chicken with high egg and meat production. Adequate nutrition is an important factor that can affect the success of livestock production. In general, the rearing system of native chicken in Indonesia still uses semi-intensive features such as using food waste as a diet causing low productivity.

The main nutrient component that has an important role for support high productivity is protein and energy. The kind feed ingredient, the most widely used protein source, are soybean meal and meat bone meal. Both feed ingredients are still imported, resulting in high feed costs and increasing production costs. Furthermore, Corn is still used as the main energy source of feed in the poultry industry, but its availability and prices fluctuate so that it is necessary to substitute feed ingredients for other energy sources. Therefore, it is necessary to explore local feed protein and energy sources that can substitute soybean meal or meat bone meal, and corn in the diet.

Indigofera is one type of legume with the potential to be a protein source with nutrient content consisting of $21.97 \%$ dry matter, $6.15 \%$ ether extract, $24.17 \%$ crude protein, $6.41 \%$ ash, $54.24 \%$ NDF, $44.69 \%$ ADF. Studies on the use of Indigofera as a protein source feed, either in the form of flour or fresh, have been widely carried out. In poultry, feeding Indigofera zollingeriana leaf meal of $5.5 \%$ in laying duck diet could stimulate produce egg low cholesterol $[4,5]$ reported using an Indigofera leaf meal of $10 \%$ in a laying quail diet not affected egg production, feed conversion ratio, or even increased the colour scale of egg yolks. Diet of broiler chicken consists of $17.74 \%$ Indigofera top leaf meal not disrupt broiler chicken health $[6,7]$ stated that using an Indigofera leaf meal of $20 \%$ in the Arabic chicken diet impacts feed conversion and egg weight. However, it did not affect feed intake and egg production. Meanwhile, rice bran is a source of feed energy that is widely used in poultry farming. [8] stated that rice bran as the major energy for laying hens diet reaches $90 \%$ composition in laying hens diet without significant negative impact on egg production, egg weight, haugh units, or shell deformation.

The use of Indigofera leaf meal and rice bran in the diet of crossbreed native chicken KUB x Sensi-1 Agrinak still needs to be evaluated. Based on the crude fibre component in Indigofera of $54.24 \% \mathrm{NDF}$ and $44.69 \% \mathrm{ADF}$, it is a limiting factor for use, especially for poultry. Similarly. The crude fibre in rice bran reaches $29.25 \%$ [9]. Broiler chicken fed carboxymethyl cellulose (CMC) of $2 \%$ and $4 \%$ reduce body weight gain and average feed intake [10]. On the other hand, the high crude fibre content in the ration will stimulate the work of the digestive tract which is reflected in the relative weight or relative length of the digestive tract. The high crude fibre content in the feed (2 vs 7\%) significantly had a higher gizzard weight in the male Venda chickens [11]. Therefore, the purpose of this study was to evaluate the effect of using Indigofera meal in crossbred native chicken (KUB x Sensi-1 Agrinak) diet on the characteristic of digestive organs.

\section{Material and methods}

\subsection{Animal and dietary treatments}

The research was conducted in Tembuku District, Bangli Regency, Bali Province in AprilAugust 2020. The experiment used 240 head DOC of KUB x SenSi Agrinak-1 crossbred native chicken. The experiment was conducted in a randomized block design with a $4 \times 2$ factorial arrangement. The first factor was diet treatment consisted of 4 types, i.e., P0, P1, P2, and P3 (Table 1). The second factor was sex consisted of 2 types, i.e., male and female 
groups. Replicated each experimental unit was 3 times, and each replicate consisted of ten crossbred native chicken. The chickens were allocated randomly in a floor pen. Also, provided diet and drinking water were ad libitum. The diet ingredients used were CP BR 115 concentrate, rice bran, Indigofera meal, corn, Bio-B probiotic (Table 1). Arranged the nutritional requirement of native chicken was into two-phase are starter (0-7 weeks) and grower (8-16 weeks).

Table 1. Ingredient and nutritional of each treatment diet (as fed)

\begin{tabular}{|l|c|c|c|c|c|c|c|c|}
\hline \multirow{2}{*}{ Ingredients } & \multicolumn{3}{|c|}{ Starter (0-7 weeks) } & \multicolumn{4}{c|}{ Grower (8-16 weeks) } \\
\cline { 2 - 9 } & P0 & P1 & P2 & P3 & P0 & P1 & P2 & P3 \\
\hline $\begin{array}{l}\text { CP BR 115 } \\
\text { Concentrate }\end{array}$ & 100 & 70 & 70 & 60 & 25 & 15 & 15 & 22 \\
\hline Rice bran & 0 & 30 & 30 & 30 & 35 & 35 & 35 & 31.5 \\
\hline Indigofera meal & 0 & 0 & 0 & 10 & 0 & 10 & 10 & 10 \\
\hline Corn & 0 & 0 & 0 & 0 & 40 & 40 & 40 & 36.5 \\
\hline Bio B & 0 & 0 & $2 \mathrm{cc} /$ liter & 0 & 0 & 0 & $2 \mathrm{cc} /$ liter & 0 \\
\hline Total & 100 & 100 & 100 & 100 & 100 & 100 & 100 & 100 \\
\hline Nutrient* & $\mathrm{P} 0$ & $\mathrm{P} 1$ & $\mathrm{P} 2$ & $\mathrm{P} 3$ & $\mathrm{P} 0$ & $\mathrm{P} 1$ & $\mathrm{P} 2$ & $\mathrm{P} 3$ \\
\hline DM (\%) & 87.00 & 87.81 & 87.81 & 88.11 & 86.35 & 86.65 & 86.65 & 86.71 \\
\hline Ash (\%) & 7.00 & 7.26 & 7.26 & 6.56 & 5.14 & 4.51 & 4.51 & 4.63 \\
\hline CP(\%) & 23.00 & 18.9 & 18.9 & 19.39 & 13.94 & 12.71 & 12.71 & 13.74 \\
\hline EE (\%) & 5.00 & 7.4 & 7.4 & 7.9 & 7.32 & 7.82 & 7.82 & 7.60 \\
\hline CF (\%) & 5.00 & 5.9 & 5.9 & 6.9 & 5.93 & 5.96 & 5.96 & 6.00 \\
\hline GE (cal/g) & 3025 & 3047 & 3047 & 2915 & 3005 & 3028.75 & 3028.75 & 3009.88 \\
\hline Ca & 0.90 & 0.65 & 0.65 & 0.58 & 0.26 & 0.19 & 0.19 & 0.25 \\
\hline P & 0.60 & 0.87 & 0.87 & 0.83 & 0.83 & 0.75 & 0.75 & 0.75 \\
\hline
\end{tabular}

*DM : Dry matter; CP : crude protein; EE : ether extract; CF : crude fibre; GE : gross energy

\subsection{Variables and sampling}

The variables measured were characteristic of digestive tracts consisted weight of each part such as gizzard, duodenum, jejunum, ileum, caecum, colon, liver, pancreas, proventriculus, and crop. Other parameters measured were a relative length of duodenum, jejunum, ileum, caecum, and colon. The variables were taken from three chickens from each replicate on the $16^{\text {th }}$ of the week.

\subsection{Statistical Analysis}

The study used a randomized block design with a $4 \times 2$ factorial assignment with three replicates, and each replication used 10 native chickens. The data were subjected to analysis of variance (ANOVA) on main and interaction effects. When founding a significant treatment effect, Duncan's Multiple Range Test was used to determine the significant difference among mean values.

\section{Results and discussion}

\subsection{Effect of concentrate substitute by Indigofera meal on digestive tract characteristics}

The data of digestive tract characteristics presented in Table Attachment 2 showed that substituted concentrate feed with Indigofera meal influenced each part's relative weight 
$(\mathrm{P}<0.05)$. The gizzard organ is important for mechanical digestion on poultry such as native chicken. The gizzard has an important function to help chickens reduce feed particle size with asymmetrical muscle contractions resulting in a rotating motion [12]. In this study, gizzard weight was affected by type diet treatment, where the gizzard of native chickens dietary $\mathrm{P} 2$ treatment has a biggest of $33.24 \mathrm{gram} / \mathrm{kg} \mathrm{BW}$ or $3.32 \% \mathrm{BW}(\mathrm{P}<0.05$; Table Attachment 2).

The weight gizzard was founded in this study appropriate with a study by [13], who reported the percentage gizzard of male native chicken of 8 weeks of age with a fed crude fibre of $6 \%$ is $3.70 \%$. The crude fibre content is known as one of the factors that can influence gizzard relative weight. The gizzard relative weight increased on 28 days of 33.88 $\mathrm{g} / \mathrm{kg} \mathrm{BW}$ in turkeys fed wood shavings and finely ground corn $[\mathbf{1 4}, \mathbf{1 5}]$ stated an increase in the proportion of gizzards along with the increase in crude fibre content of the diet. Feeds with high crude fibre require stronger gizzard muscles to reduce particle size. This activity increases in gizzard size and weight [15]. In formulation, P2 treatment uses probiotic Bio B $2 \mathrm{cc} /$ liter to improve crude fibre digestibility. Probiotic also possible has contribute impact on gizzard relative weight $(\mathrm{P}<0.05$; Table Attachment 2$)$. The present finding agrees with those of [16], who reported that gizzard and proventriculus weight of broiler chicken grower phase higher when probiotic, prebiotic, and symbiotic supplemented than control.

The relative weight of the duodenum was influenced by treatments $(\mathrm{P}<0.05$; Table Attachment 2), where treatment $\mathrm{P} 0-\mathrm{B}$ has a bigger duodenum than other treatments. Relative weight the duodenum $\mathrm{P} 0-\mathrm{B}$ of $9.57 \mathrm{gram} / \mathrm{kg} \mathrm{BW}$ or $0.96 \%$ The relative weight duodenum in this study higher than study by [17], who reported relative weight the duodenum of female native chicken fed high crude fibre is 4.56 gram or $0.54 \%$. Development of intestinal is not specific determined on the duodenum, jejunum or ileum but is more determined by digestive activity and absorption activity of diet [18]. Crude protein content of $23 \%$ in $\mathrm{P} 0$ stater diet possible stimulate duodenum relative weight. The relative weight of duodenum was influenced by crude protein content in diet, where relative weight duodenum higher on broiler chicken fed control 100\% ideal protein starter diet and $130 \%$ ideal protein starter diet than chicken fed restriction intake [19].

Interaction diet treatment and sex impact jejunum relative weight $(\mathrm{P}<0.05$; Table Attachment 2). The biggest jejunum relative weight was founded in P1-J treatment of 17.79 gram $/ \mathrm{kg} \mathrm{BW}$ or $1.18 \% \mathrm{BW}$. The P1 diet treatment has a relative weight jejunum of 16.22 gram $/ \mathrm{kg} \mathrm{BW}(1.62 \% \mathrm{BW})$. Moreover, male native chicken has bigger jejunum than female native chicken $(\mathrm{P}<0.05)$. The relative weight jejunum in this study higher than study by [17], who reported relative weight the jejunum of male native chicken fed high crude fibre is 8.56 gram or $0.83 \% \mathrm{BW}$. The jejunum of male native chicken bigger than jejunum of female native chicken on 28 days age [20]. Jejunum has a function for nutrient absorption continued after the duodenum [2]. Intestinal development is not specific in certain parts, as is the case with the duodenum. The development of the jejunum is more determined by the level of nutrient absorption. There are two hypotheses related to increases in intestinal relative weight. The first hypothesis is that the relative weight gain of intestinal shows inefficiency nutrient digest and the second hypothesis is the relative weight gain of intestinal is following the increase in growth performance [19]. The jejunum size, which was heavier than other treatments, was indicated due to the administration of $10 \%$ Indigofera supplements. Indigofera meal can be absorbed well so that it positively impacts the production performance.

Ileum has a function to water and mineral absorption [2]. In this study, the biggest ileum was founded in P0-B treatment of $15.35 \mathrm{gram} / \mathrm{kg} \mathrm{BW}$ or $1.54 \% \mathrm{BW}$. The relative weight ileum in this study higher than study by [17], who reported relative weight the ileum of female native chicken fed high crude fibre is 6.25 gram or $0.74 \% \mathrm{BW}$. Based on ileum function is possible relative weight of ileum showed that absorption water and mineral in 
female native chicken fed P0 treatment more efficient. In this study, caecum relative weight was influenced by diet treatment, where native chicken fed P1 treatment have bigger caecum than other treatment $(\mathrm{P}<0.05$; Table Attachment 2). Caecum has an important function for electrolyte and water absorption. Other than that, the caecum can enlarge due to an increased amount of fermentable material in the diet [5]. Based on this information, the possibility of the caecum in the P1 treatment was greater than the other treatments, causing the P1 diet to have more fermentable ingredients without probiotic supplementation. This condition also occurs in the colon relative weight where native chicken fed $\mathrm{P} 1$ treatment has a heavier colon than other diet treatments $(\mathrm{P}<0.05$; Table Attachment 2).

Relative weight large intestine was founded ranges 1.82-3.47 gram $/ \mathrm{kg} \mathrm{BW}$, where native chicken fed P1 diet treatment has a relative weight large intestine of $3.47 \mathrm{gram} / \mathrm{kg}$ $\mathrm{BW}$ or $0.35 \% \mathrm{BW}$. This value is almost the same as that reported by [17] who reported relative weight of large intestine native chicken ranges $0.20-0.27 \% \mathrm{BW}$. Large intestine also has a fermentation function due to microbial activity. Large intestine and caecum enlarge directly related to an animal ability to digest fibrous materials [8]. Based on this information, the possibility of the large intestine in the P1 treatment was greater than the other treatments, causing the P1 diet to have more fermentable ingredients without probiotic supplementation. Interaction diet treatments and sex was affected to the relative weight of the liver $(\mathrm{P}<0.05$; Table Attachment 2). The heaviest of liver was founded in male native chicken fed P3 treatment, while the lightest was founded in female native chicken fed P3 treatment. Meanwhile, the type of diet factor is known to affect the relative weight of liver where native chicken fed P3 diet show the heaviest liver. The relative weight of the liver was founded in this study appropriate with a study by [21], who stated that the addition of insoluble fibre $1 \%$ of diet show increase liver relative weight of laying hens. The increase of the liver relative weight was caused by higher liver activity in breaking down glycogen into glucose which decreased due to the high crude fibre content in the diet [22].

Interaction diet treatments and sex was affected to the relative weight of the pancreas $(\mathrm{P}<0.05$; Table Attachment 2). The heaviest of pancreas was founded in male native chicken fed P1 treatment (3.01 gram $/ \mathrm{kg} \mathrm{BW),} \mathrm{while} \mathrm{the} \mathrm{lightest} \mathrm{was} \mathrm{founded} \mathrm{in} \mathrm{female}$ native chicken fed P3 treatment (1.27 gram $/ \mathrm{kg} \mathrm{BW})$. The male native chicken has a heavier pancreas than the female native chicken [23]. Meanwhile, the type of diet factor is known to affect the relative weight of pancreas where native chicken fed P1 diet show the heaviest pancreas $(2.88 \mathrm{gram} / \mathrm{kg} \mathrm{BW})$. The relative weight of the pancreas was founded in this study appropriate with a study by [21], who stated that the addition of insoluble fibre $1 \%$ of diet show increase pancreas relative weight of laying hens. Proventriculus and crop was influenced by interaction diet treatment and sex $(\mathrm{P}<0.05$; Table Attachment 2). Proventriculus or glandular stomach has an important function of chemical digestion of nutrients with the way secreting endogenous enzyme (hydrochloric acid and pepsinogen) [24]. The male native chicken fed $\mathrm{P} 2$ treatment has the biggest proventriculus of 4.95 gram $/ \mathrm{kg} \mathrm{BW}$ or $0,49 \%$ BW. However, the female native chicken fed P2 and P3 treatment has the smallest proventriculus of 3.76 and $3.29 \mathrm{gram} / \mathrm{kg} \mathrm{BW}$, respectively. The relative weight proventriculus was founded in this study smaller than the study by [25], who reported that the relative weight of proventriculus of super native chicken 60 days of age is $0.63 \% \mathrm{BW}$. The effect of crude fibre on the relative weight of proventriculus still cannot be clearly determined. [26] reported that broiler chicken fed sugar beet pulp has a more increased relative weight of proventriculus than oat hulls treatment. Likewise, [27] stated that broiler chicken was fed wood shavings has heavier proventriculus than another kind of fibre (whole wheat and cellulose. Based on this study, effect of fibre on the digestive organs is also determined by the type of fibre given. 
The crop has a function as a feed storage container on poultry. Furthermore, the crop also impacts nutrient digestion using digesta softening and mixing feed with exogenous and endogenous enzymes or microbial enzymes [38]. In this study, relative weight of the crop influenced by interaction between diet treatments and sex $(\mathrm{P}<0.05$; Table Attachment 2). Male native chicken was fed P1 treatment has a greater crop (5.63 gram $/ \mathrm{kg} \mathrm{BW}$ ) than other treatment. The relative weight of the crop found in this study was close to that reported by [17], who reported that the relative weight of the native chicken crop was 6.11 grams or $0.68 \%$. The high crude fibre content in diet causing the rate of diet slowly so that the diet is stored longer in crop and results in a heavier crop work [29].

The crude fibre content in diet also has a significant effect on the relative length of the digestive tract between the duodenum, jejunum, ileum, caecum and large intestine $(\mathrm{P}<0.05$; Table 3). The effect of crude fibre is not specific to any particular part of the digestive tract. Duodenal length was significantly affected, where domestic chickens fed P3 had the longest duodenum, which was $36.00 \mathrm{~cm}$. In this study, the duodenum was founded longer than the study by [17], who reported that the duodenum length of female native chicken of 22.33 $\mathrm{cm}$. The effect of diet treatment was also found to vary on the relative lengths of the jejunum, ileum, caecum and large intestine. The relative length of the jejunum was found in native chickens fed P1 and P2 treatments $(56.50 \mathrm{~cm}$ and $54.83 \mathrm{~cm})$, where the longest jejunum was founded in male native chickens fed P1 diet treatment. The length of the jejunum in this study appropriate with the study by [17], who reported the length of the jejunum of native chicken ranges between 52-53,40 cm. Meanwhile, the length ileum, caecum and large intestine found in this study are $68.00,17.00$ and $6.50 \mathrm{~cm}$, respectively. In general, this condition occurs in chickens fed P1 diet except for caecum. The length of the caecum has a positive correlation on the relative weight of caecum also showed that P2 diet treatment more impact on caecum causing in P2 diet had probiotic content. Probiotic content in the P2 diet stimulates caecum work causing produces greater caecum. Based on this information, the high crude fibre content in the diet could stimulate intestinal length. The high crude fibre content in the ration has a different impact on each part of the digestive tract but based on the evaluation of the final weight of the chicken, the use of Indigofera flour can reach $10 \%$ and $35 \%$ rice bran in the ration without the addition of probiotics.

Table 3. Effect of diet treatment and sex on relative length digestive organs

\begin{tabular}{|l|l|l|l|l|l|}
\hline \multirow{2}{*}{ Treatments } & \multicolumn{5}{|c|}{ Parameters $(\mathrm{cm})$} \\
\cline { 2 - 6 } & \multicolumn{1}{|c|}{ Duodenum } & \multicolumn{1}{|c|}{ Jejunum } & \multicolumn{1}{c|}{ Ileum } & \multicolumn{1}{c|}{ Caecum } & Large Intestine \\
\hline P0-J & $31.00 \pm 6.00^{\mathrm{ab}}$ & $44.67 \pm 3.51^{\mathrm{ab}}$ & $51.00 \pm 2.00^{\mathrm{a}}$ & $13.00 \pm 0.00^{\mathrm{ab}}$ & $6.00 \pm 1.00^{\mathrm{abc}}$ \\
\hline P1-J & $29.00 \pm 1.00^{\mathrm{a}}$ & $61.00 \pm 5.00^{\mathrm{c}}$ & $68.00 \pm 1.00^{\mathrm{c}}$ & $14.00 \pm 2.00^{\mathrm{abc}}$ & $7.00 \pm 1.00^{\mathrm{c}}$ \\
\hline P2-J & $27.00 \pm 5.00^{\mathrm{a}}$ & $59.00 \pm 7.00^{\mathrm{c}}$ & $63.00 \pm 5.00^{\mathrm{bc}}$ & $17.00 \pm 2.00^{\mathrm{c}}$ & $6.00 \pm 0.00^{\mathrm{abc}}$ \\
\hline P3-J & $27.67 \pm 2.52^{\mathrm{a}}$ & $51.67 \pm 4.51^{\mathrm{bc}}$ & $54.00 \pm 3.61^{\mathrm{ab}}$ & $16.33 \pm 1.53^{\mathrm{c}}$ & $5.00 \pm 0.50^{\mathrm{ab}}$ \\
\hline P0-B & $29.67 \pm 1.53^{\mathrm{a}}$ & $58.00 \pm 10.00^{\mathrm{c}}$ & $60.00 \pm 11.00^{\mathrm{abc}}$ & $16.33 \pm 3.51^{\mathrm{c}}$ & $5.33 \pm 1.53^{\mathrm{abc}}$ \\
\hline P1-B & $26.00 \pm 2.00^{\mathrm{a}}$ & $52.00 \pm 7.00^{\mathrm{bc}}$ & $55.67 \pm 7.51^{\mathrm{ab}}$ & $15.67 \pm 0.58^{\mathrm{bc}}$ & $6.00 \pm 1.00^{\mathrm{abc}}$ \\
\hline P2-B & $26.00 \pm 4.00^{\mathrm{a}}$ & $50.67 \pm 1.53^{\mathrm{bc}}$ & $52.00 \pm 2.00^{\mathrm{a}}$ & $12.00 \pm 0.00^{\mathrm{a}}$ & $4.33 \pm 0.58^{\mathrm{a}}$ \\
\hline P3-B & $36.00 \pm 1.00^{\mathrm{b}}$ & $40.00 \pm 1.00^{\mathrm{a}}$ & $54.33 \pm 0.58^{\mathrm{ab}}$ & $12.67 \pm 0.58^{\mathrm{ab}}$ & $6.67 \pm 0.58^{\mathrm{bc}}$ \\
\hline Factor A : Diet Treatments & $30.33 \pm 3.98^{\mathrm{ab}}$ & $51.33 \pm 9.91^{\mathrm{ab}}$ & $55.50 \pm 8.62^{\mathrm{ab}}$ & $14.67 \pm 2.88^{\mathrm{a}}$ & $5.67 \pm 1.21^{\mathrm{ab}}$ \\
\hline P0 & $27.50 \pm 2.17^{\mathrm{ab}}$ & $56.50 \pm 7.34^{\mathrm{b}}$ & $61.83 \pm 8.28^{\mathrm{b}}$ & $14.83 \pm 1.60^{\mathrm{a}}$ & $6.50 \pm 1.05^{\mathrm{b}}$ \\
\hline P1 & $26.50 \pm 4.09^{\mathrm{a}}$ & $54.83 \pm 6.43^{\mathrm{b}}$ & $57.50 \pm 6.92^{\mathrm{ab}}$ & $14.50 \pm 3.02^{\mathrm{a}}$ & $5.33 \pm 0.82^{\mathrm{a}}$ \\
\hline P2 & $31.83 \pm 4.88^{\mathrm{b}}$ & $45.83 \pm 7.03^{\mathrm{a}}$ & $54.17 \pm 2.32^{\mathrm{a}}$ & $14.50 \pm 2.26^{\mathrm{a}}$ & $5.83 \pm 0.98^{\mathrm{ab}}$ \\
\hline P3 & $28.67 \pm 3.87^{\mathrm{a}}$ & $54.08 \pm 8.05^{\mathrm{a}}$ & $59.00 \pm 7.65^{\mathrm{a}}$ & $15.08 \pm 2.19^{\mathrm{a}}$ & $6.00 \pm 0.95^{\mathrm{a}}$ \\
\hline Factor B : Sex & $29.42 \pm 4.77^{\mathrm{a}}$ & $50.17 \pm 8.47^{\mathrm{a}}$ & $55.50 \pm 5.49^{\mathrm{a}}$ & $14.17 \pm 2.46^{\mathrm{a}}$ & $5.58 \pm 1.21^{\mathrm{a}}$ \\
\hline Male & Female &
\end{tabular}




\section{Conclusion}

The use of $10 \%$ Indigofera meal and $35 \%$ rice bran in ration crossbred native chicken (KUB x SenSi-1 Agrinak) affected the relative weight and length of the digestive tract but did not have a negative effect on animal growth. The effect of crude fibre on the characteristics of the digestive tract varied depending on the type of crude fibre and organ function. based on the evaluation of the final weight of the chicken, the use of Indigofera flour can reach $10 \%$ and $35 \%$ rice bran in the ration without the addition of probiotics.

\section{References}

1. H. Resnawati, JPIP 5, 2 (2012).

2. S. Satimah, V.D. Yunianto, F. Wahyono, JSPI 14, 4 (2019).

3. M. Ardiyana, C. Sumantri, S. Murtini, T. Sartika, J. I. Produksi Teknol. Hasil Peternakan 6, 2 (2018).

4. N.M.J. Arini, Sumiati, R. Mutia, JITAA 42, 3 (2017).

5. Svihus, J. Appl. Poult. Res. 23, (2014).

6. M.A. Santi, JPI 1, 2 (2017).

7. M.A. Pagala, A. Bain, A. Surajat, JITRO 5, 1 (2018).

8. Varastegani, I. Dahlan, J. Anim. Pro. Adv 4, 6 (2014).

9. F.R. Wolayan, J.S. Mandey., JOAAT 6, 1 (2019).

10. Rahmatnejad, A.A. Saki, Anim Physiol Anim Nutr 100, 4 (2015).

11. M.M. Ginindza, J. W. Ng'Ambi, D. Norris, Indian J. Anim. Res 51, 6 (2017).

12. S. Urfa, H. Indrijani, W. Tanwiriah, Jurnal Ilmu Ternak 17, 1 (2017).

13. G.G. Maradon, R. Sutrisna, Erwanto, JIPT 3, 2 (2015).

14. F.B.O. Santos, A.A. Santos Jr., P.R. Ferket, B.W. Sheldon, International Journal of Poultry Science 5, 8 (2006).

15. M. Purba, L.H. Prasetyo, JITV 19, 3 (2014).

16. H.M. Abdel-Hafeez, E.S.E. Saleh, S.S. Tawfeek, Asian-Australas J. Anim. Sci. 30, 5 (2017).

17. R.A. Widyanata. Skripsi. Fakultas Peternakan Institut Pertanian Bogor, (2013).

18. M. Yegani, D.R. Korver, Poult. Sci. J 87, (2008).

19. P.J.A. Wijtten, E. Hangoor, J.K.W.M. Sparla, M.W.A. Verstegen, Poult. Sci 89, (2010).

20. S. Iskandar, JITV 9, 4 (2004).

21. J.S. Yokhana, G. Parkinson, T.L. Frankel, Poult. Sci. J 95, 3 (2015).

22. U. Hatta, Rusdi, R. Arief, J. Agroland 16, 1 (2009).

23. Parchami, S. Kusha, VRF 6, 4 (2015).

24. Rodrigues, M. Choct, Poult Sci 97, (2018).

25. Badrussalam, Isroli, T. Yudiarti, JSPI 15, 3 (2020).

26. E.J. Moreno, J.M.G. Alvarado, A.G. Serrano, R. Lazaro, G.G. Mateos, Poult. Sci. J 88, (2009).

27. A.M. Amerah, V. Ravindran, R.G. Lentle, Br. Poult. Sci 50, 3 (2009).

28. H.L. Classen, J. Apajalahti, B. Svihus, M. Choct, Worlds. Poult. Sci. J 72, (2016).

29. Maulana, I.M. Suasta, D.P.M.A. Candrawati, JTAPRO 8, 2 (2020). 
Table Attachment 2. Effect of diet treatment and sex on relative weight digestive organs

\begin{tabular}{|c|c|c|c|c|c|c|c|c|c|c|c|}
\hline \multirow[b]{2}{*}{ Treatments } & \multicolumn{11}{|c|}{ PARAMETERS (g/kg BW) } \\
\hline & $\begin{array}{c}\text { Final } \\
\text { Weight } \\
\text { (Gram) }\end{array}$ & Gizzard & Duodenum & Jejunum & Ileum & Caecum & $\begin{array}{c}\text { Large } \\
\text { Intestine }\end{array}$ & Liver & Pancreas & Proventiculus & Crop \\
\hline P0-J & $1250 \pm 65^{b}$ & $31.05 \pm 3.59^{\mathrm{a}}$ & $7.54 \pm 0.27^{\mathrm{a}}$ & $9.80 \pm 3.15^{\mathrm{ab}}$ & $10.27 \pm 3.35^{\mathrm{ab}}$ & $6.36 \pm 0.31^{\mathrm{ab}}$ & $2.09 \pm 0.22^{\mathrm{a}}$ & $20.94 \pm 2.60^{\mathrm{ab}}$ & $1.61 \pm 0.67^{\mathrm{a}}$ & $3.92 \pm 0.48^{\mathrm{ab}}$ & $3.42 \pm 0.63^{\mathrm{ab}}$ \\
\hline P1-J & $1107 \pm 87^{\mathrm{ab}}$ & $27.88 \pm 2.06^{\mathrm{a}}$ & $8.85 \pm 0.33^{\text {abc }}$ & $17.79 \pm 2.88^{\mathrm{c}}$ & $15.06 \pm 1.26^{\mathrm{c}}$ & $6.73 \pm 0.15^{\mathrm{ab}}$ & $4.22 \pm 1.78^{a}$ & $21.06 \pm 0.60^{\mathrm{ab}}$ & $3.01 \pm 0.17^{\mathrm{d}}$ & $4.16 \pm 0.64^{\text {abc }}$ & $5.63 \pm 2.03^{\mathrm{c}}$ \\
\hline P2-J & $1213 \pm 58^{b}$ & $33.85 \pm 3.87^{\mathrm{a}}$ & $8.15 \pm 0.85^{\mathrm{ab}}$ & $16.50 \pm 2.70^{\mathrm{de}}$ & $15.19 \pm 0.80^{\circ}$ & $7.76 \pm 0.89^{\circ}$ & $2.51 \pm 0.12^{\mathrm{a}}$ & $23.90 \pm 0.96^{\mathrm{ab}}$ & $2.53 \pm 0.31^{\text {bcd }}$ & $4.95 \pm 0.23^{\mathrm{c}}$ & $3.08 \pm 0.08^{\mathrm{ab}}$ \\
\hline P3-J & $1125 \pm 155^{\text {ab }}$ & $25.52 \pm 0.06^{\mathrm{a}}$ & $8.93 \pm 0.77^{\mathrm{bc}}$ & $13.32 \pm 8.99^{\text {bed }}$ & $13.20 \pm 1.49^{\mathrm{bc}}$ & $5.31 \pm 1.03^{\mathrm{a}}$ & $1.70 \pm 0.19^{\mathrm{a}}$ & $28.51 \pm 0.59^{\mathrm{c}}$ & $2.70 \pm 0.31^{\text {bcd }}$ & $4.59 \pm 0.56^{\mathrm{bc}}$ & $4.20 \pm 0.23^{\mathrm{abc}}$ \\
\hline P0-B & $1020 \pm 55^{\mathrm{a}}$ & $21.85 \pm 1.09^{\mathrm{a}}$ & $9.57 \pm 0.61^{\mathrm{c}}$ & $12.63 \pm 2.46^{\text {abcd }}$ & $15.38 \pm 3.46^{\mathrm{c}}$ & $6.03 \pm 1.09^{\mathrm{ab}}$ & $1.58 \pm 0.25^{\mathrm{a}}$ & $25.12 \pm 2.29^{\mathrm{bc}}$ & $1.85 \pm 0.68^{\text {abc }}$ & $3.97 \pm 0.48^{\mathrm{abc}}$ & $4.41 \pm 0.55^{\mathrm{bc}}$ \\
\hline P1-B & $990 \pm 75^{\mathrm{a}}$ & $26.15 \pm 9.64^{a}$ & $9.08 \pm 1.35^{\mathrm{bc}}$ & $14.66 \pm 2.08^{\text {cde }}$ & $12.05 \pm 3.70^{\mathrm{abc}}$ & $7.34 \pm 1.06^{\mathrm{bc}}$ & $2.72 \pm 0.64^{\mathrm{a}}$ & $21.18 \pm 3.82^{\mathrm{ab}}$ & $2.74 \pm 0.71^{\mathrm{cd}}$ & $4.39 \pm 0.82^{\mathrm{bc}}$ & $2.69 \pm 0.19^{\mathrm{a}}$ \\
\hline P2-B & $994 \pm 4^{a}$ & $32.63 \pm 0.30^{a}$ & $7.99 \pm 0.64^{\mathrm{ab}}$ & $10.78 \pm 0.57^{\text {abc }}$ & $12.05 \pm 0.32^{\text {abc }}$ & $5.33 \pm 0.48^{\mathrm{a}}$ & $1.51 \pm 0.44^{\mathrm{a}}$ & $23.71 \pm 3.56^{\mathrm{ab}}$ & $1.81 \pm 0.45^{\mathrm{ab}}$ & $3.76 \pm 0.24^{\mathrm{ab}}$ & $3.70 \pm 0.32^{2 \mathrm{ab}}$ \\
\hline P3-B & $1140 \pm 35^{\mathrm{ab}}$ & $30.35 \pm 0.38^{\mathrm{a}}$ & $8.12 \pm 0.02^{\mathrm{ab}}$ & $8.99 \pm 1.55^{\mathrm{a}}$ & $8.28 \pm 0.53^{\mathrm{a}}$ & $5.82 \pm 0.95^{\text {ab }}$ & $1.94 \pm 0.15^{\text {a }}$ & $20.62 \pm 0.10^{\mathrm{a}}$ & $1.27 \pm 0.22^{\mathrm{a}}$ & $3.29 \pm 0.56^{\mathrm{a}}$ & $3.35 \pm 0.23^{\mathrm{ab}}$ \\
\hline \multicolumn{12}{|c|}{ Factor A : diet treatments } \\
\hline P0 & $1135 \pm 137^{\mathrm{a}}$ & $26.45 \pm 5.57^{\mathrm{a}}$ & $8.56 \pm 1.19^{\mathrm{a}}$ & $11.21 \pm 2.97^{\mathrm{a}}$ & $12.83 \pm 4.14^{\mathrm{a}}$ & $6.20 \pm 0.74^{\mathrm{ab}}$ & $1.84 \pm 0.35^{\text {a }}$ & $23.03 \pm 3.17^{\mathrm{ab}}$ & $1.73 \pm 0.62^{a}$ & $3.94 \pm 0.43^{\mathrm{a}}$ & $3.92 \pm 0.76^{\mathrm{a}}$ \\
\hline $\mathrm{Pl}$ & $1048 \pm 97^{\mathrm{a}}$ & $27.02 \pm 6.30^{\mathrm{a}}$ & $8.97 \pm 0.89^{\mathrm{a}}$ & $16.22 \pm 2.82^{\circ}$ & $13.55 \pm 2.97^{a}$ & $7.30 \pm 0.75^{\mathrm{b}}$ & $3.47 \pm 1.45^{b}$ & $21.12 \pm 2.44^{\mathrm{a}}$ & $2.88 \pm 0.49^{\mathrm{b}}$ & $4.28 \pm 0.67^{\mathrm{a}}$ & $4.16 \pm 2.06^{\mathrm{a}}$ \\
\hline P2 & $1103 \pm 125^{\mathrm{a}}$ & $33.24 \pm 2.54^{\mathrm{b}}$ & $8.07 \pm 0.68^{\mathrm{a}}$ & $13.64 \pm 3.59^{\mathrm{ab}}$ & $13.62 \pm 1.80^{\mathrm{a}}$ & $6.55 \pm 1.47^{\mathrm{ab}}$ & $2.01 \pm 0.62^{\mathrm{a}}$ & $23.81 \pm 2.34$ ab & $2.17 \pm 0.52^{\mathrm{a}}$ & $4.35 \pm 0.68^{\mathrm{a}}$ & $3.39 \pm 0.40^{\mathrm{a}}$ \\
\hline P3 & $1133 \pm 101^{a}$ & $27.94 \pm 2.66^{\mathrm{a}}$ & $8.53 \pm 0.66^{a}$ & $11.16 \pm 2.57^{\mathrm{a}}$ & $10.74 \pm 2.88^{a}$ & $5.57 \pm 0.93^{\mathrm{a}}$ & $1.82 \pm 0.20^{\mathrm{a}}$ & $24.56 \pm 4.34^{b}$ & $1.99 \pm 0.82^{\mathrm{a}}$ & $3.94 \pm 0.86^{\mathrm{a}}$ & $3.78 \pm 0.51^{\mathrm{a}}$ \\
\hline \multicolumn{12}{|l|}{ Factor B : sex } \\
\hline Male & $1174 \pm 105^{b}$ & $29.58 \pm 4.08^{a}$ & $8.37 \pm 0.79^{\mathrm{a}}$ & $14.35 \pm 3.88^{\mathrm{b}}$ & $13.43 \pm 2.67^{a}$ & $6.54 \pm 1.09^{a}$ & $2.63 \pm 1.26^{\mathrm{b}}$ & $23.60 \pm 3.44^{\mathrm{a}}$ & $2.46 \pm 0.65^{\mathrm{b}}$ & $4.40 \pm 0.59^{\mathrm{a}}$ & $4.08 \pm 1.37^{\mathrm{a}}$ \\
\hline Female & $1036 \pm 105^{\mathrm{a}}$ & $27.75 \pm 5.97^{\mathrm{a}}$ & $8.69 \pm 0.98^{\mathrm{a}}$ & $11.76 \pm 2.69^{\mathrm{a}}$ & $11.94 \pm 3.41^{a}$ & $6.13 \pm 1.11^{\mathrm{a}}$ & $1.94 \pm 0.61^{\mathrm{a}}$ & $22.66 \pm 3.10^{\mathrm{a}}$ & $1.92 \pm 0.72^{\mathrm{a}}$ & $3.85 \pm 0.63^{\mathrm{a}}$ & $3.54 \pm 0.72^{\mathrm{a}}$ \\
\hline
\end{tabular}

